\title{
Cleft hand/foot: clinical and developmental aspects
}

\author{
Paul W Buss
}

\begin{abstract}
Isolated limb reduction defects occur in approximately 1 in 2000 live births within which central ray anomalies are an important subgroup. Most affected persons have mild or moderate functional impairment. Considerable psychological morbidity may also occur. While there have been major strides forwards in our understanding of vertebrate limb development, the mechanisms responsible for central ray deformities remain poorly understood. Several case reports of central clefting anomalies associated with chromosomal rearrangements or interstitial deletions of 7q21.2-q21.3 suggest that this chromosomal region is important for limb development.
\end{abstract}

(F Med Genet 1994;31:726-730)

While the term ectrodactyly literally means "missing digits", it is now used as a descriptive term for a central ray anomaly that presents clinically as a central cleft of the hands or feet. ${ }^{1}$ Historically, terms such as "lobster claw" and split hand ${ }^{3}$ have been used to describe this defect which results from absence, or reduction, of one or more of the three central digits (fig 1). The earliest known description of cleft hand was that by Pare $^{4}$ although Barsky suggested that this report represented two fingered hemimelia rather than true cleft hand. Central ray defects, according to Swanson's modified classification, represent terminal longitudinal limb anomalies. ${ }^{6}$ Cleft limb has a number of associations and as a result it can be

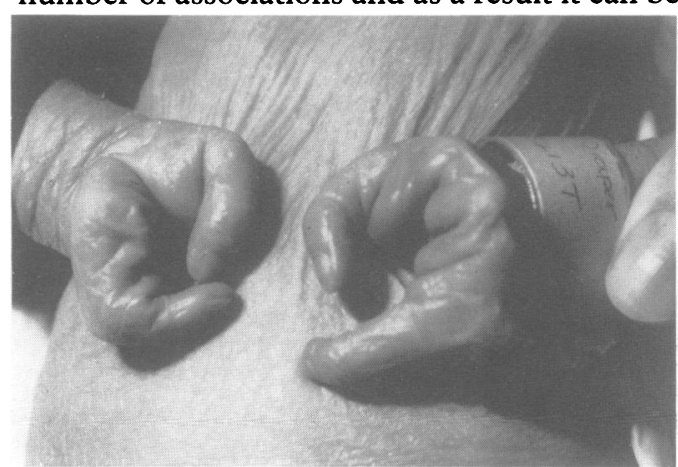
this case the child had EEC syndrome.

\footnotetext{
Dr Buss, Department of Paediatrics, Royal Gwent Hospital, Newport, Gwent NP9 2UB, UK.

Department of University of Bristol, Bristol BS2 8EG, UK P W Buss

a useful major feature for syndrome diagnosis.

Large families with isolated cleft limbs have been described which usually show autosomal dominant inheritance and marked variability in expression and penetrance, ${ }^{7}$ although several autosomal recessive pedigrees have also been reported. $^{8-10}$ Birch-Jensen ${ }^{11}$ estimated the incidence of cleft hand deformity at 1 in 90000 births. More recent epidemiological studies suggest the incidence of central ray anomalies to be closer to 1 in 10000 (approximately 0.7 per 10000 live births). ${ }^{1213}$ The data of Czeizel et $a l^{14}$ indicate that three-quarters $(77 \%)$ of cases present with unimelic involvement.

In 1960 Stevenson and Jennings ${ }^{15}$ suggested an abnormal segregation pattern in families with isolated ectrodactyly (pedigree analysis showed an excess of affected sons of affected fathers). David, ${ }^{16}$ when describing three pedigrees with isolated cleft limbs, suggested the possibility of germinal mosaicism. X linked inheritance has also been described in a seven generation Pakistani kindred. ${ }^{17}$

Ford ${ }^{18}$ hypothesised that "ectrodactyly" represented an anomaly that could be explained by a structural chromosomal defect although at that time it was acknowledged that techniques for chromosome analysis were poor. Since then a number of case reports have indicated that the $7 \mathrm{q} 21.2-\mathrm{q} 21.3$ region is a candidate site for cleft limbs. ${ }^{19-26}$ These have resulted in considerable molecular interest in this region.

\section{Clinical features}

Clinical problems associated with isolated cleft hand and foot are usually cosmetic and psy-

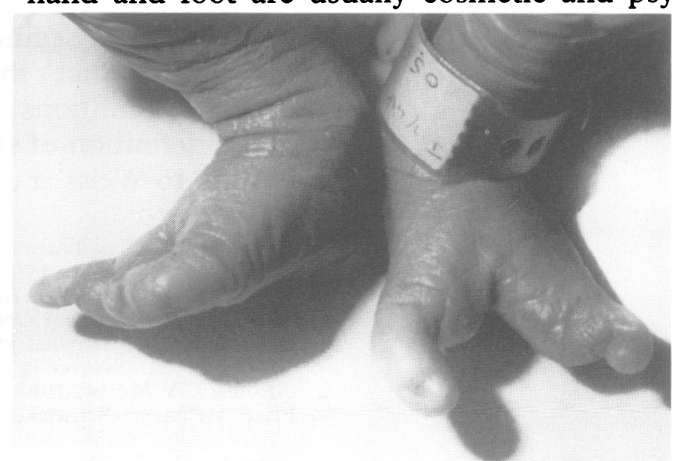

Figure 1 Typical central clefts of hands and feet; wide central clefts with normal marginal (radial and ulnar) rays. In 
Table 1 List of conditions in which cleft limb may be a feature (McKusick No)

EEC syndrome (129900)

Cornelia de Lange syndrome (122430)

Acrorenal syndrome (102520)

Focal dermal hypoplasia (305600)

Ectrodactyly and cleft palate syndrome (129830)

Ectrodactyly and cleft palate syndrome (129830)

Ectrodactyly and macular dystrophy (185800)

Non-specific associations with several anomalies are noted by Czeizel $e t a^{1+}$ and also with neural tube defects.

chological rather than functional. Only in the less common variant monodactylous ectrodactyly, where radial rays are also hypoplastic, is function severely compromised. Considerable anatomical variability occurs. Cleft hand has been described with pre- and postaxial duplication and reduction anomalies. Absence of the central digits is the major feature with varying association with both bony and soft tissue syndactyly. Many cases will merely have one limb affected and others can have tetramelic involvement. Birch-Jensen ${ }^{11}$ found that $58 \%$ of cases of cleft hands were bilateral with an equal sex distribution. These clinical findings were confirmed by Barsky. ${ }^{5}$ The majority of cases of cleft hand are sporadic. In Birch-Jensen's study, ${ }^{11} 50 \%$ had a family history of limb defects while only $20 \%$ of Barsky's group 5 were familial. The study of Czeizel et $a l^{14}$ showed a high percentage of presentation as atypical forms, though this is based on a "wide" interpretation as to what actually constitutes atypical split hand/foot. The definition of this varies between published reports but actually serves relatively little clinical purpose. It is also subject to wide differences in clinical interpretation. A consensus might be that atypical cleft limb occurs when there is not total absence of the long finger or when there are, in addition, reduction anomalies affecting the marginal rays. This tends to be (though not always) sporadic and unilateral, affecting mainly the upper limbs.

Clinically, few functional problems occur in the upper limbs provided opposition is possible. However when a preaxial anomaly coexists or when monodactyly (a single digit) occurs, marked limitation of function can result. Functional limitation can result when central clefts are particularly wide or deep and operative management to close these can often result in significant improvement in function. Limitation of function owing to syndactyly of the fingers may also occur and this also can be overcome surgically. ${ }^{27}$ In the lower limbs the major practical difficulty encountered is one of obtaining adequately wide fitting shoes.

Many persons with "ectrodactyly" experience psychological problems. These often emerge in mid-childhood as a reluctance to use hands, even a need to hide them. Non-verbal communication may be affected by this and common important gestures, such as hand shaking, are often avoided. These problems have frequently not been overcome even in adult life (Buss, unpublished data). Providing adequate reassurance to parents of affected children may allow them to help their children develop a positive body image. Anecdotal reports of cases with tetrameiic involvement who are professional artists, speed typists, and even marathon runners may also be of considerable reassurance.

Radiology usually reflects the clinical findings but sometimes transverse metacarpals or proximal phalanges affect the appearance. Occasionally atypical cleft hand and monodactyly coexist (fig 2). In the EEC syndrome (the ectodermal dysplasia, ectrodactyly, and clefting syndrome), preaxial anomalies also may coexist with a central cleft. While careful examination of the parents' hands may be helpful, there is little extra information to be gained from routine radiography of the hands and feet of parents who are clinically normal.

\section{Differential diagnosis: clinical approach}

Recognition of a central ray deformity may be a useful clue for the diagnosis of a number of underlying disorders (EEC syndrome, Cornelia de Lange syndrome, acrorenal syndrome, etc) (table 1). When presented with a neonate with a central ray defect diagnostic difficulties may arise. In such cases magnification of nails and dental $x$ rays may help in identifying involvement of ectodermal structures (difficult in the neonate/infant with oligosymptomatic EEC syndrome). It is also worthwhile reviewing these children during the first year to confirm normal development of ectodermal structures and, if uncertain of this, electron microscopic examination of the hair shaft may be helpful in diagnosing ectodermal dysplasia (Buss, unpublished data). In the newborn it is important to document hair distribution and birth weight. A renal ultrasound scan may help make the diagnosis of the EEC or acrorenal syndrome. In older children and adults with "isolated" ectrodactyly, one often notes minor associated ectodermal anomalies (of the teeth in particular). ${ }^{1}$ Language milestones should be checked. Ectrodactyly associated with conductive deafness and mandibular hypoplasia has been described in a father and son by Patterson and Stevenson ${ }^{28}$ and more recently with sensorineural deafness by Raas-Rothschild et $a l^{29}$ although the latter report looks distinctly similar to oligosymptomatic EEC syndrome. The otic capsule is interestingly also of ectodermal origin. ${ }^{30}$ Opitz and Frias ${ }^{31}$ described an association with cleft palate as a separate entity, the ECP syndrome. Karsch ${ }^{32}$ recognised

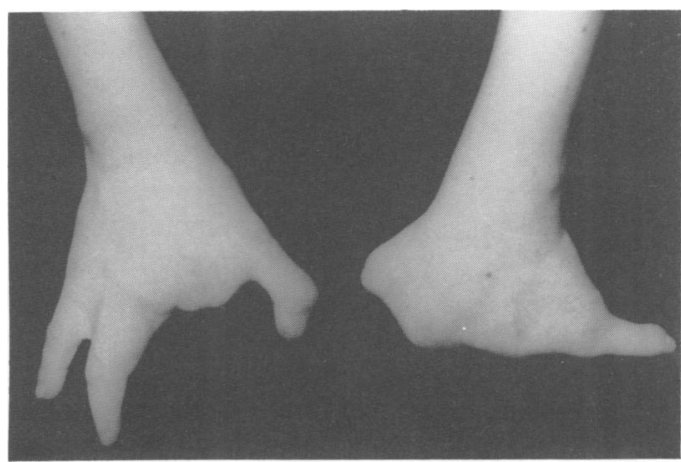

Figure 2 Combined monodactyly with atypical cleft deformity showing some preservation of marginal rays in right hand. 
Table 2 Review of reported cases of ectromelia associated with anomalies of chromosome $7 q 21$

\begin{tabular}{|c|c|c|}
\hline Author & Clinical description & $7 q$ deletion/karyotype \\
\hline Del Porto et al ${ }^{19}$ & $\begin{array}{l}\text { Male infant, low set ears, hypotonia, beaked nose, bilateral } \\
\text { cleft foot }\end{array}$ & $\operatorname{del}(7)(\mathrm{q} 11-\mathrm{q} 21$ or $\mathrm{q} 22)$ \\
\hline Pfiefer et $a l^{20}$ & $\begin{array}{l}\text { Female aged } 2 \text { years, microcephaly, low set ears, mental } \\
\text { retardation, cleft palate, } R \text { cleft hand and foot }\end{array}$ & $\operatorname{del}(7)(\mathrm{q} 11.2-\mathrm{q} 22.1)$ \\
\hline Tajara et $a l^{21}$ & $\begin{array}{l}\text { Male aged } 3 \text { years, microcephaly, anteverted nares, } \\
\text { micrognathia, retardation, clefting of three limbs }\end{array}$ & $\operatorname{del}(7)(\mathrm{q} 11.2-\mathrm{q} 22)$ \\
\hline Morey et $a l^{22}$ & $\begin{array}{l}\text { Premature male, } \mathrm{R} \text { cleft hand, amelia of lower limbs, facial } \\
\text { dysmorphism, ASD. Died at } 7 \text { months }\end{array}$ & $\operatorname{del}(7)(\mathrm{q} 21.3-\mathrm{q} 31.3)$ \\
\hline Sharland et $a l^{23}$ & $\begin{array}{l}\text { Male infant, tetramelic ectrodactyly, low set ears, } \\
\text { hypertelorism }\end{array}$ & $\begin{array}{l}\text { Complex rearrangement } \mathrm{t}(5 ; 7 ; 9) \\
\text { with breaks at } 7 \mathrm{q} 21.2 \text { and } 7 \mathrm{q} 31.3\end{array}$ \\
\hline Roberts et $a l^{24}$ & $\begin{array}{l}\text { Male, tetramelic ectrodactyly, mild facial dysmorphism and } \\
\text { mild developmental delay }\end{array}$ & $\begin{array}{l}\text { Complex rearrangement } \\
\text { (intrachromosomal) del(7) } \\
\text { (q21.3-22.1) }\end{array}$ \\
\hline Naritomi et al ${ }^{25}$ & Male, trimelic ectrodactyly, bifid uvula, high arched palate & $\begin{array}{l}\text { ins }(3 ; 7)(\mathrm{q} 21 ; \mathrm{q} 34 \mathrm{q} 22) . \text { Break at } \\
7 \mathrm{q} 22 \mathrm{q} 34\end{array}$ \\
\hline Genuardi $e t a l^{26}$ & $\begin{array}{l}5 \text { generation family, } 7 \text { affected, } 5 \text { male. Unimelic ( } 3 \text { cases), } \\
\text { tetramelic ( } 4 \text { cases). Two with sensorineural deafness. One } \\
\text { case with tibial hypoplasia }\end{array}$ & $\begin{array}{l}\text { Balanced translocation } \mathrm{t}(2 ; 7) \\
(\mathrm{q} 21.1 ; \mathrm{q} 22.1)\end{array}$ \\
\hline
\end{tabular}

an association with impaired vision owing to cataract and macular dystrophy.

For parents of isolated cases empirical recurrence risks are low but there is a potential risk to offspring of affected persons of $50 \%$. With possible heterogeneity and altered penetrance risks may be lower. ${ }^{33}$ Certainly isolated cleft limbs can produce some very difficult diagnostic as well as counselling situations. Constriction amputation of digits may be difficult to distinguish from unimelic atypical cleft limb. Clues as to a constrictive aetiology might include the observation of amniotic strands at birth or lymphoedema distal to a possible constriction ring. Soft tissue syndactyly also occurs in constriction anomalies but is usually distal. ${ }^{34}$ In such cases no other bony anomalies are usually radiologically present and occasionally the astute neonatal resident will have asked for the placenta to be examined showing an amniotic tear. Unilateral limb reduction deficits may also have a vascular origin and the clinician should be aware of relevant points in the history, for example, chorionic villus sampling, presence of twins (reversed arterial perfusion), and any occurrences that may have compromised fetal circulation. It can be difficult to separate some of these potential causes and in the atypical isolated unimelic case explanation of a number of potential aetiologies may occasionally be necessary.

\section{Cleft hand and foot malformation and $7 q$ abnormalities}

Eight recent case reports of ectrodactyly and $7 \mathrm{q} 21.2-\mathrm{q} 21.3$ anomalies are summarised in table 2. It is of interest that six of seven isolated cases reported are male (note the preponderance of males observed by Stephenson and Jennings ${ }^{15}$ and in the familial cases of Czeizel et $a l^{14}$ ). The significance of this is unclear. Genuardi $e t a^{26}$ recently reported a family segregating a balanced translocation with a breakpoint at 7q22.1, in which two out of nine translocation carriers had limb deficiencies (similar abnormalities were present in a further five persons in whom chromosome analysis was not possible). Overall there is a wide range of clinical involvement from apparently isolated cleft limbs to ectromelia associated with fatal anomalies. None of the isolated cases had uni- lateral cleft limbs, although three members of a family ${ }^{26}$ showed unimelic involvement. The majority of the reported cases have typical cleft limbs.

Few other reports exist that link central ray anomalies with chromosome 7. Klep-de Pater et $a l^{35}$ described a female infant with cleft palate and digital reduction deformities of the second and fifth digits of the right hand (not typical central cleft) and no evidence of ectodermal dysplasia. ${ }^{35}$ This case had a karyotype $46, \mathrm{XX}$, $\operatorname{del}(7)$ (q11 $\rightarrow q 22)$. A number of additional case reports of deletions involving the $7 \mathrm{q} 22$ band have not been associated with ectrodactyly. ${ }^{36}$

\section{Aetiology and developmental aspects}

The general association of cleft limb with anomalies of ectodermal structures is not particularly surprising as there are similarities in limb development to that of several ectodermal structures. Wolpert's experiments which confirmed earlier observations of a crucial reliance of embryonic limb ectoderm on the underlying mesoderm are not merely of historical importance. ${ }^{37} \mathrm{He}$ postulated the presence of a signalling mechanism (probably a diffusible morphogen) which could be interpreted as a positional signal for regional development within the progress zone of the developing limb bud mesoderm. Historically it has seemed likely that the endogenous signalling morphogen in the limb bud of mammals may be related to retinoic acid (possibly $3^{\prime} 4^{\prime}$ didehydroretinoic acid). ${ }^{38}$ However an exciting recent report indicates that a newly identified gene encoding the signalling molecule, Sonic hedgehog, may be involved in establishing polarising activity in the developing limb bud and hence anteroposterior patterning. ${ }^{39}$

Developmental digit anomalies such as those seen in central ray anomalies, however, are not easily explained by a diffusible morphogen model. Homeobox genes are consistently expressed in the developing limb bud and digits in a way that reflects their location within a homeobox cluster (temporospatial colinearity). ${ }^{40}$ These genes are activated sequentially by varying concentrations of retinoic acid within the limb bud. The expression of genes of the homeobox 4 (HOX D) type is necessary for normal limb development in mice ${ }^{41}$ and chick. ${ }^{42}$ Transcript expression can be predictably 
altered in experimental animal models by implantation of retinoic acid soaked beads in strategic positions within the developing limb bud with resultant anomalies ${ }^{43}$ including mirror hands and polydactyly. Central ray digit reduction anomalies have not yet been observed in these experiments. It may be that the anomaly represents a localised disturbance of HOX expression at the ectodermal/mesodermal junction. Recent work has shown distinct expression of MSX1 (HOX 7) and MSX2 $\left(\right.$ HOX 8) at this site in limbs ${ }^{445}$ and teeth. ${ }^{46}$ Additionally combined expression of both HOX D and of HOX A (localised to $7 \mathrm{p} 11$ ) appears necessary for organised cellular differentiation in the developing limb bud. The msh related MSX1 and MSX2 genes, although widely distributed in the early limb bud, are later organised at the distal part of the bud and are responsible for limb growth, possibly by maintaining a pool of undifferentiated cells at the progress zone ${ }^{47}$ Although great strides have been made in our knowledge of vertebrate limb patterning in the context of central ray anomalies, it must also be conceded that currently there are no obvious developmental genes which map to the $7 \mathrm{q}$ candidate region. In addition there are no ectrodactylous mouse mutants which map to the homologous region on mouse chromosome 5 . It is interesting to note, however, that mutation of MSX2 (HOX 8 ) has been associated with craniosynostosis and limb defects (including triphalangeal thumb and metatarsal shortening). ${ }^{48}$

Mice have been bred with dactylaplasia which closely resembles the human cleft limb. In these it has been hypothesised that the anomaly occurs as a result of effects from two loci. ${ }^{49}$ Whether this could be extrapolated to human cleft limb is debatable but a similar explanation was put forward by David. ${ }^{16}$ The association of cleft limb with absence of long bones $^{50}$ suggests that the defect may occasionally be a result of a common defect in regional limb specification. A child exposed in utero to a retinoic acid derivative during the crucial time of limb development with absent digits and syndactyly has been reported. ${ }^{51}$ More recently two case reports of limb anomalies in a fetus and child with prenatal exposure to isotretinoin have been reported. ${ }^{52}$ One could postulate that the mechanism underlying this may be a failure of differentiation resulting from misexpression of homeobox genes. However, it may be worth noting that other teratogens such as ethanol have also been postulated to cause ectrodactyly, ${ }^{53}$ in this particular case with no clear underlying mechanism.

Evidence is clearly accumulating to make the $7 \mathrm{q} 21.2-\mathrm{q} 21.3$ locus a prime candidate for isolated ectrodactyly. While it has also been postulated as a locus for investigation in syndromes such as the EEC syndrome ${ }^{54}$ (contiguous genes), it is likely that cleft limb represents a genetically heterogeneous condition and the $7 \mathrm{q}$ genes represent just one potential defect affecting a common pathway for limb differentiation.
The author wishes to acknowledge that his work on cleft limbs was conducted as Action Research Training Fellow in Medical Genetics at the Institute of Medical Genetics, University of Wales College of Medicine, Cardiff.

1 Tentamy S, McKusick V. The genetics of hand malformations. New York: Alan A Liss, 1978:53-63.

2 Goldmann EE. Beitrag zur Lehre von der Misbuldingen der Extremetaten. Beitr Klin Chir 1891;7:239-56.

3 Meller J. Ein Fall von angeborer Spaltbilding der Hande und Fusse. Berl Klin Wochenschr 1893;30:232-3.

4 Pare A. Les oeuvres de M Ambroise Pare. Paris: Gabriel Boun, 1575:5-8.

5 Barsky A. Cleft hand, classification, incidence and treatment. $\mathcal{F}$ Bone Hand Surg ( $\mathrm{Am}$ ) 1964;46:1707-19.

6 Swanson A. A classification for congenital limb defects. $\mathcal{F}$ Hand Surg 1978;1:8-12.

7 Lewis T, Embleton D. Split hand and split foot deformities their types, origin and transmission. Biometrika 1908;6: $26-58$.

8 Verma I, Joseph R, Bharjansa S, Sadanand M. Split hand and split foot deformity inherited as an autosomal recessive trait. Clin Genet 1976;9:8-14.

9 Zlotogora J, Nubani N. Is there an autosomal recessive form of split hand and split foot malformation? $\mathcal{f}$ Med Genet 1988;25:138-40.

10 Friere Maia N. Autosomal recessive form of ectrodactyly and its implications in genetic counselling. $\mathcal{f}$ Hered 1971 ; 62:53

11 Birch-Jensen A. Congenital deformities of the upper extremities. Copenhagen: Ejnar Munksgaard, 1949.

12 Froster UG, Baird P. Limb reduction defects in over 1 million consecutive live births. Teratology 1989;39:127-35.

13 Calzolari E, Manioguigi O, Garani GP, Cocchi G, Magnani C, Milan M. Limb reduction defects in Emilia Romagna Italy: epidemiological and genetic study in 173109 consecutive live births. $\mathcal{f}$ Med Genet 1990;29:353-7.

14 Czeizel AE, Vitez M, Kodaj T, Lenz W. An epidemiological study of isolated split hand/foot in Hungary, 1975-1984. f Med Genet 1993;30:593-6.

15 Stevenson A, Jennings L. Ectrodactyly - evidence in favour of disturbed segregation in offspring of affected males. Ann Hum Genet 1960;24:89-96.

16 David TJ. Dominant ectrodactyly and possible germinal mosaicism. ₹ Med Genet 1972;9:316-20

17 Ahmad M. Abbass H, Haque S, Gebjard F. X-chromosomally inherited split-hand/split foot anomaly in a mosomally inherited split-hand/split foot anom

18 Ford CE. Autosomal anomalies. Second Conference on Congenital Malformations, NY Foundation, 1963:25.

19 Del Porto G, D'Alessandro E, De Matties C, LoRe M, DiFusco I. Delzione interstiziale del braccio lungo del cromosoma 7 e sue correlzioni cliniche. Pathologica (Suppl) 1983;75:268-71.

20 Pfiefer RA. Interstitial deletion of chromosome 7(q11.2 q22.1) in a child with split hand/split foot malformation. Ann Genet (Paris) 1984;27:45-8

21 Tajara EH, Varella-Garcia M, Gusson ACT. Interstitial long arm deletion of chromosome 7 and ectrodactyly. $A m \mathcal{F}$ Med Genet 1989;32:192-4.

22 Morey MA, Higgins RR. Ectro-amelia syndrome associated with an interstitial deletion of 7q. Am F Med Genet 1990; 35:95-9.

23 Sharland M, Patton M, Hill L. Ectrodactyly of hands and feet in a child with a complex translocation including feet in a child with a complex transloca

24 Roberts SH, Hughes HE, Davies SJ, Meredith AL. Bilateral split hand and foot malformation in a boy with a de novo interstitial deletion of $7 \mathrm{q} 21.3$. F Med Genet 1991;28: 479-81

25 Naritomi K, Izumikawa Y, Tohma T, Hirayama K. Inverted insertion of chromosome 7q and ectrodactyly. Am $\mathcal{F ~ M e d ~}$ Genet 1993;46:492-3.

26 Genuardi M, Maria GP, Vincenza S, Bellussi A, Zollini M, Neri G. Split hand/split foot anomaly in a family segregating a balanced translocation with a breakpoint on 7q22.1. Am ₹ Med Genet 1993;47:823-31.

27 Nutt JN, Flatt AE. Congenital central hand deficit. 7 Hand Surg 1981;6:48-60.

28 Patterson TJS, Stevenson AC. Craniofacial dysostosis and malformation of the feet. $\mathcal{F}$ Med Genet 1964;1:112-14.

29 Raas-Rothschild A, Aviram A, Ben-Ami T, et al. Newly recognised ectrodactyly/deafness syndrome. f Craniofac Genet Dev Biol 1989;9:121-7

30 Mikaelian DO, Der Kalousten VM, Shahin NA Congenital ectrodactyly with hearing loss. Arch Otolaryngol 1970;92: ectrod.

31 Opitz J, Frias JL. The ECP syndrome, another autosomal dominant cause of monodactylous ectrodactyly. Eur f Ped 1980;133:217-20.

32 Karsch J. Erbliche augenmissbildung in verbindung mit spalthand und fuss. $Z$ Augenheilkd 1936;89:274-9.

33 Emery AEH. A problem for genetic counselling - split hand deformity. Clin Genet 1977;12:125-7.

34 Gellis S. Constrictive bands in the human. Birth Defects 1977;13(1):259-68

35 Klep-de Pater JM, Bijlsma JB, Bleeker-Wagemakers EM. Two cases with different deletions of chromosome 7. $\mathcal{F}$ Med Genet 1979;15:161-3.

36 Winter R, Tickle C. Syndactylies and polydactylies - embryological overview and suggested classification. Eur $\mathcal{f}$ Hum Genet 1993;1:96-104.

37 Wolpert L. Mechanisms of limb development and malformation. Br Med Bull 1976;32:65-70. 
38 Ragsdale CW Jr, Brockes J. Retinoids and their targets in vertebrate development. Curr Opin Cell Biol 1992;3 928-34.

39 Riddle RD, Johnson RL, Laufer E, Tabin C. Sonic hedgehog mediates the polarizing activity of the ZPA. Cell 1993;75: 1401-16

40 Lewis T A gene complex controlling segmentation in drosophila. Nature 1978;276:565.

41 Dolle P, Izpisua-Belmonte JC, Falkinstein H, Renucci A Duboule D. Coordinate expression of murine Hox 5 complex homeobox containing genes during limb pattern formation. Nature 1989;342:767-9.

42 Izisua-Belmonte JC, Tickle C, Dolle P, Wolpert L, Douboule D. Expression of the homeobox HOX 4 genes and the specification of position in chick wing development. Nature 1991;350:585-9.

43 Bryant SV, Gardiner DM. Retinoic acid, local cell-cel interactions and pattern formation in vertebrate limbs Dev Biol 1992;152:1-25.

44 Benoit R, Lyons G, Simandl BK, Atshushi R, Buckingham $M$. The apical ectodermal ridge regulates Hox 7 and $\operatorname{Hox}$ 8 gene expresssion in developing chick limb buds. Genes Dev 1991;5:2363-74.

45 Davidson D, Crawley A, Hill RE, Tickle C. Position dependent expression of two related homeobox genes in developing vertebrate limbs. Nature 1991;352:429-31.
46 McKenzie A, Leeming GL, Tarrett, Jowett A, Sharpe PT. Human Hox 7 in regional and temporal expression in craniofacial and tooth development. Developmemt 1991 111:269-85.

47 Tickle C. A tool for transgenesis. Nature 1992;358:188-9. 48 Wang Jabs E, Muller I, Li X, et al. A mutation in the homeodomain of the human MSX2 gene in a family affected with autosomal dominant craniosynostosis. Cell 1993;75:443-50.

49 Chai CK. Dactylaplasia in mice. F Hered 1981;72:234-7.

50 Hoyme AD, Lyons K, Nyhan W, Pauli R, Robinow M Autosomal dominant ectrodactyly and abnormalities of long bones of upper and lower limbs. $\mathcal{F}$ Pediatr 1987;111: long bones

51 McBride WG. Limb reduction deformities in a child exposed to ide $\mathrm{W}$. Limb reduction deformities in a child exposed to isoretinoin

52 Rizzo R, Lammer E, Parsano E, Pavone L, Arglyle JC. Limb reduction defects in humans associated with prenata isoretinoin exposure. Teratology 1991;44:599 604.

53 Hermann J, Pallister PD, Opitz JM. Tetraectrodactyly and other skeletal manifestations in the foetal alcohol syndrome. Eur $\mathcal{F}$ Pediatr 1980;133:221-6.

54 Qumiseyeh MB. EEC syndrome (ectodermal dysplasia, ectrodactyly, cleft lip and palate) is on $7 \mathrm{q} 11.2-\mathrm{q} 21.3$. Clin Genet 1992;42:101. 